\title{
Effect of increasing levels of rice distillers' by-product on growth performance, nutrient digestibility, blood profile and colonic microbiota of weaned piglets
}

\author{
Oanh Nguyen Cong ${ }^{1,2}$, Bernard Taminiau ${ }^{3}$, Dang Pham Kim², Georges Daube ${ }^{3}$, Giap Nguyen Van ${ }^{4}$, \\ Jérôme Bindelle ${ }^{5}$, Papa Abdulaye Fall ${ }^{6}$, Ton Vu Dinh², and Jean-Luc Hornick,*
}

\footnotetext{
* Corresponding Author: Jean-Luc Hornick Tel: +32-0-4-366-41-12, Fax: +32-0-4-366-41-16, E-mail: jlhornick@uliege.be

${ }^{1}$ Department of Veterinary Management of Animal Resources, FARAH Center, Faculty of Veterinary Medicine, University of Liège, 4000 Liège, Belgium 2 Faculty of Animal Science, Vietnam National University of Agriculture, Hanoi Capital 100000, Vietnam

${ }^{3}$ Department of Food Sciences, FARAH Center, Faculty of Veterinary Medicine, University of Liège, 4000 Liège, Belgium

${ }^{4}$ Faculty of Veterinary Medicine, Department of Microbiology-Infectious Diseases, Vietnam National University of Agriculture, Hanoi 100000, Vietnam ${ }^{5}$ Animal Science Unit, GemABT, University of Liège, 5030 Gembloux, Belgium

${ }^{6}$ Genalyse Partner SA, Rue Hayeneux 62, B-4040 Herstal, Belgium
}

ORCID

Oanh Nguyen Cong

https://orcid.org/0000-0001-7549-3389

Bernard Taminiau

https://orcid.org/0000-0001-6456-329X

Dang Pham Kim

https://orcid.org/0000-0002-7110-2552

Georges Daube

https://orcid.org/0000-0002-9282-8408

Giap Nguyen Van

https://orcid.org/0000-0001-5250-1825

Jérôme Bindelle

https://orcid.org/0000-0001-6974-4313

Papa Abdulaye Fall

https://orcid.org/0000-0003-4045-4448

Ton Vu Dinh

https://orcid.org/0000-0002-7907-5456

Jean-Luc Hornick

https://orcid.org/0000-0003-1831-1440

Submitted Apr 4, 2019; Revised May 7, 2019; Accepted Jul 6, 2019
Objective: This study was conducted to evaluate the effects of diets containing different wet rice distillers' by-product (RDP) levels on growth performance, nutrient digestibility, blood profiles and gut microbiome of weaned piglets.

Methods: A total of 48 weaned castrated male crossbred pigs, initial body weight $7.54 \pm 0.97 \mathrm{~kg}$, and age about $4 \mathrm{wks}$, were used in this experiment. The piglets were randomly allocated into three iso-nitrogenous diet groups that were fed either a control diet, a diet with 15\% RDP, or a diet with $30 \% \mathrm{RDP}$ for a total of 35 days. Chromium oxide was used for apparent digestibility measurements. On d 14 and d 35, half of the piglets were randomly selected for hemato-biochemical and gut microbiota evaluations.

Results: Increasing inclusion levels of RDP tended to linearly increase $(\mathrm{p} \leq 0.07)$ average daily gain on $\mathrm{d} 14$ and $\mathrm{d} 35$, and decreased $(\mathrm{p}=0.08)$ feed conversion ratio on $\mathrm{d} 35$. Empty stomach weight increased $(\mathrm{p}=0.03)$ on $\mathrm{d} 35$ while digestibility of diet components decreased. Serum globulin concentration decreased on d $14(\mathrm{p}=0.003)$ and red blood cell count tended to decrease $(p=0.06)$ on $d 35$, parallel to increase RDP levels. Gene amplicon profiling of $16 \mathrm{~S}$ rRNA revealed that the colonic microbiota composition of weaned pigs changed by inclusion of RDP over the period. On d 14, decreased proportions of Lachnospiraceae_ge, Ruminococcaceae_ge, Ruminococcaceae_UCG-005, and Bacteroidales_ge, and increased proportions of Prevotellaceae ge, Prevotella_2, and Prevotella 9 were found with inclusion of RDP, whereas opposite effect was found on d 35. Additionally, the proportion of Lachnospiraceae ge, Ruminococcaceae_ge, Ruminococcaceae_UCG-005, and Bacteroidales_ge in RDP diets decreased over periods in control diet but increased largely in diet with 30\% RDP.

Conclusion: These results indicate that RDP in a favorable way modulate gastrointestinal microbiota composition and improve piglet performance despite a negative impact on digestibility of lipids and gross energy.

Keywords: Blood Profiles; Colonic Microbiota; Growth Performance; Rice Distillers' By-product; Weaned Piglet

\section{INTRODUCTION}

Rice distillers' by-product (RDP) is a widespread coproduct from alcohol industry in Vietnam and in Asia, and is an excellent source of protein, fiber, and minerals [1-3]. It also contains other nutrients generated from fermented rice $[4,5]$. Owing to its cheap price it could thus help to replace more expensive feed sources for swine $[3,6]$. Moreover, in pig production, dietary modulation was considered as strategic ways for reducing enteric diseases, improve gut health, and enhance growth performance [7-11]. Interestingly, diets containing agroindustrial by-products from ethanol production are known to reduce diarrhea incidence 
in weaned piglets [12]. Furthermore, piglets fed RDP diet showed increased acetic and lactic acid content in hindgut [13], and lower populations of pathogenic bacteria in digestive tract [14]. Increase in apparent ileal digestibility (AID) of crude protein (CP) [13] was found in piglets fed RDP. Additionally, a level of $4 \% \mathrm{RDP}$ in pig diet showed to be effective as a prebiotic including positive effect on pig performance and health $[15,16]$. To the best of our knowledge, to date, studies on effect of RDP on piglet performance are still limited. Moreover, no data are reported on effect of RDP on blood characteristics, and gut microbiota composition using $16 \mathrm{~S}$ rRNA gene-based metagenomic analysis. Hence, links between growth performance, plasma parameters and intestinal microbiota are fully lacking. Thus, the main objectives of this study were to compare growth performance, nutrient digestibility, blood profiles, and colonic bacterial microbiota between weaned piglets fed diets containing increasing amounts of RDP.

\section{MATERIALS AND METHODS}

\section{Animal care}

In the absence of proper regulation on the use of animals for research and animal welfare during experiments in Vietnam, the protocols were carried out according to the best practices usually accepted by the Ethical Committee of University of Liège (Belgium) when conducting similar experiments.

\section{Rice distillers' by-product used}

The RDP originated from a glutinous rice alcohol manufacturer in the Phu Loc village, Hai Duong province in the Red River Delta region in Vietnam. The RDP was obtained from rice distillation under traditional alcohol production process. Briefly, rice was heated over steam and then spread out on a flat surface to allow cooling. Yeast was then sprinkled over rice and both were well mixed. Preparation was placed in lidded buckets for incubation for about three days. The buckets were then filled with water and held for about one week. Finally, alcohol was distilled through a covered pot and steam ducted away to a water-cooled condenser. The residues were considered as RDP for pig feeding. The RDP samples were collected immediately after alcohol distillation for chemical analysis prior to diet formulation for the trial.

\section{Experimental design}

The study was carried out from January to March 2017 at a private farm specialized in pig production, in Hai Duong province, located $40 \mathrm{~km}$ from the Vietnam National University of Agriculture (VNUA), Hanoi, Vietnam. A total of 48 healthy weaned castrated male crossbred pigs ( $\lesssim$ Duroc $\times \bigcirc$ [Landrace $\times$ Yorkshire]), originating from 12 sows to 4 male piglets per sow, 3 to 5 litter order, initial body weight (IBW) $7.54 \pm 0.97 \mathrm{~kg}$ (mean \pm standard deviation), and age about 4 wks, were used in this experiment. The piglets were individually ear tag numbered and randomly allocated into three diet-groups of four blocks according to similar IBW and sow origin by treatment. There were four replicate pens (block) per treatment and 4 pigs per concrete pen $(3.6 \times 1.1 \mathrm{~m})$ with a height of $0.6 \mathrm{~m}$, each pen equipped with stainless steel feeding trough and 2 automatic water-drinking nipples. In each pen, a $(1.2 \times 0.6 \mathrm{~m})$ plywood piece and a $175 \mathrm{~W}$ red infrared heat lamp bulb were used in order to maintain effective temperature for pig development. The room temperature was kept at approximately $30^{\circ} \mathrm{C}$ the first week, and afterwards was decreased by $1^{\circ} \mathrm{C}$ each week of the experiment, suitable for animal development. Piglets were fed one of three diets (a control diet without $\mathrm{RDP}, \mathrm{RDP} 0$; and two experimental diets with 15\%, RDP15; and 30\%, RDP30; RDP on a DM basis) during a total of 35-d experiment for 2 stages (early phase, from $\mathrm{d} 0$ to $\mathrm{d} 14$; and late phase from $\mathrm{d} 15$ to $\mathrm{d} 35)$. Chromium oxide $\left(\mathrm{Cr}_{2} \mathrm{O}_{3}\right)$ added at $5 \mathrm{~g} / \mathrm{kg}$ dry matter (DM) of diet was used as digesta flow marker to measure digestibility. On d 14 and d 35, two pigs per pen were randomly selected and transported 4 hours after feeding from the farm to Faculty of Veterinary Medicine, VNUA (about one hour quite travel in suitable vehicle). These pigs rested for one hour and were then killed for collection of digesta and intestinal tissue samples.

\section{Ingredients, diets, feeding and animal management}

Raw feed ingredients were purchased all at once from a local feed company, except RDP which was delivered daily from the manufacturer. Feed was ground into flour through a 2 $\mathrm{mm}$ screen before mixing. The ingredients were formulated in order to obtain three iso-nitrogenous experimental diets. The RDP0 mainly consisted of corn, soybean, rice, fishmeal, and their by-products. Other diets (RDP15 and RDP30) were formulated separately with the same ingredients as the control diet, until RDP was extemporaneously included at 15\% or $30 \%$ in the diets, on a DM basis (Table 1).

At each feeding, RDP0 diet was weighed and moistened with drinking water $(\mathrm{pH}$ 6.73) at a 1:1 ratio in order to prevent losses and to facilitate intake, and the two other ones were mixed with RDP. Prior to diet allocation, feed $\mathrm{pH}$ was measured, as possible covariate factor of other parameters such as palatability. Samples of RDP and complete diets at feeding were collected one time per week and stored at $-20^{\circ} \mathrm{C}$ until the end of the experiment where they were thawed and homogenized for chemical analysis (Table 1). Daily feed allowance was divided into four equal amounts and was offered at 06:00, 11:00, 16:00, and 20:00 $\mathrm{h}$ during the entire experimental period. Diet amounts were increased gradually parallel to piglet development, at about $4 \%$ of live weight. Refusals were collected just before each feeding, weighed, stored at $-20^{\circ} \mathrm{C}$ until the end of the experimental period where they were thawed 
Table 1. Ingredients and nutrient composition of the experimental diets

\begin{tabular}{|c|c|c|c|}
\hline \multirow{2}{*}{ Items } & \multicolumn{3}{|c|}{ Dietary treatment $^{1)}$} \\
\hline & RDPO & RDP15 & RDP30 \\
\hline \multicolumn{4}{|l|}{ Ingredients (\% DM) } \\
\hline Corn $7.5 \% \mathrm{CP}$ & 9 & 13 & 15 \\
\hline Corn thermally treated & 24 & 30 & 31 \\
\hline Soybean meal $46 \%$ CP & 10 & 5 & 2 \\
\hline Soybean full fat extruded $36 \%$ CP & 20 & 15 & 7.85 \\
\hline Fishmeal $60 \%$ CP & 5 & 5 & 5 \\
\hline Broken rice & 20.9 & 9.85 & 5 \\
\hline Rice bran (full fat) & 9 & 5 & 2 \\
\hline Rice distillers' by-product $\left.{ }^{2}\right)$ & 0 & 15 & 30 \\
\hline Limestone 38\% & 1.2 & 1.2 & 1.2 \\
\hline $\mathrm{Cr}_{2} \mathrm{O}_{3}$ & 0.5 & 0.5 & 0.5 \\
\hline Salt & 0.2 & 0.2 & 0.2 \\
\hline Vitamin mineral premix ${ }^{3)}$ & 0.25 & 0.25 & 0.25 \\
\hline \multicolumn{4}{|l|}{$\begin{array}{l}\text { Analyzed composition (\% DM) and } \\
\text { energy value (MJ/kg DM) }\end{array}$} \\
\hline Dry matter & 38.6 & 38.2 & 24.0 \\
\hline Crude protein & 24.1 & 24.0 & 23.9 \\
\hline Ether extract & 5.87 & 6.26 & 8.09 \\
\hline Ash & 6.43 & 5.61 & 5.38 \\
\hline Crude fiber & 4.17 & 4.20 & 5.26 \\
\hline Neutral detergent fiber & 40.7 & 43.1 & 37.8 \\
\hline Acid detergent fiber & 6.64 & 7.87 & 6.43 \\
\hline Starch & 48.5 & 45.0 & 44.5 \\
\hline Calcium & 0.83 & 0.73 & 0.65 \\
\hline Total phosphorus & 0.61 & 0.65 & 0.70 \\
\hline Gross energy (MJ/kg DM) & 19.1 & 19.4 & 19.7 \\
\hline Metabolisable energy ${ }^{4)}$ (MJ/kg DM) & 15.5 & 16.0 & 16.1 \\
\hline Lysine & 1.29 & 1.17 & 1.07 \\
\hline Methionine & 0.42 & 0.47 & 0.53 \\
\hline
\end{tabular}

DM, dry matter; $C P$, crude protein.

1) RDP0, control diet; RDP15, diet with rice distillers' by-product accounting for 15\% DM; RDP30, diet with rice distillers' by-product accounting for 30\% DM.

${ }^{2)}$ Analyzed data (\% DM): dry matter, 8.12; crude protein, 35.28; ether extract, 0.7; neutral detergent fiber, 28.10; acid detergent fiber, 16.50; calcium, 0.14; total phosphorus, 0,42; gross energy (MJ/kg DM), 12.83; pH, 3.07; lactic, acetic, and butyric acid (g/100 $\mathrm{g}$ fresh sample), 2.07, 0.03, 0.04; ethanol (mg/kg fresh sample), 6.2 .

${ }^{3)}$ Premix contains (each $\mathrm{kg}$ of premix): vitamin $\mathrm{A}, 6,000,000 \mathrm{IU}$; vitamin $\mathrm{D}_{3}$, $800,000 \mathrm{IU}$; vitamin E+polyphenols, 20,000 mg; vitamin E, 15,000 mg; niacin, 10,000 mg; acid pantothenic, 4,000 mg; vitamin $B_{2}, 1,600$ mg; vitamin $K_{3}, 800$ mg; vitamin $B_{1}, 400$ mg; vitamin $B_{6}, 400$ mg; axit foric, 400 mg; biotin, 40,000 mcg; vitamin $B_{12}, 8,000$ mcg; Zn, 100,000 to $110,000 \mathrm{mg} ; \mathrm{Cu}_{1} 64,000$ to 70,400 $\mathrm{mg} ; \mathrm{Fe}, 48,000$ to $52,800 \mathrm{mg} ; \mathrm{Mn}, 24,000$ to $26,400 \mathrm{mg} ; \mathrm{l}, 1,600$ to $1,760 \mathrm{mg}$; $\mathrm{Se}, 120$ to $132 \mathrm{mg}$; moisture, $10 \%$.

4) Calculated data according to equation of [63] for ME estimation: $M E=4,168-12.3 \times$ Ash+1.4 $\times$ CP+4.1 $\times \mathrm{EE}-6.1 \times \mathrm{CF}(\mathrm{g} / \mathrm{kg} \mathrm{DM})$.

and homogenized for DM analysis. Pigs always had free access to water by nipple drinkers.

\section{Measurements}

Animal performance, visceral organ weight, and gastrointestinal $p H$ : Piglets were individually weighed on $\mathrm{d} 0, \mathrm{~d} 14$, and $\mathrm{d}$ 35 of the experiment. Average daily DM feed intake, average daily gain (ADG), and feed conversion ratio (FCR) were calculated for each pen, diet group, and each experimental period. On d 14 and d 35, the heart, liver, kidney, spleen, lung, stomach, small intestine, and large intestine of the killed pigs were immediately collected, blotted using absorbent paper, and then weighed (VIBRA balance, Tokyo, Japan). Digesta from stomach, small intestine and large intestine were carefully removed before organs weighing. The $\mathrm{pH}$ of stomach, ileum, caecum, and colon digesta were measured immediately after removal of segments using an electrode of a portable pH meter (HANNA, Singapore).

Digestibility: For apparent total tract digestibility (ATTD), fecal samples from each pen were collected two times per day for the last 5 days of the experiment and stored $-80^{\circ} \mathrm{C}$. At the end of the collection, the fecal samples from animals in each diet group were thawed, mixed and pooled, after which they were dried and analyzed for ATTD estimation. For AID, individual ileal digesta samples on d 35 were collected immediately post-mortem, at distal ileum about $10 \mathrm{~cm}$ anterior to ileo-caecal valve, and stored at $-80^{\circ} \mathrm{C}$ until further analysis. The ileal digesta samples from animals in each diet group were then thawed, mixed and pooled, after which they were dried and analyzed for AID estimation. The AID and ATTD of nutrients were calculated relative to the chromium content using the following equation [17]:

$$
\begin{aligned}
& \text { Nutrient digestibility (\% of intake) } \\
& =\left[1-\frac{\mathrm{Cr}_{2} \mathrm{O}_{3}(\text { diet }) \times \text { nutrient }(\text { ileum } / \text { feces })}{\mathrm{Cr}_{2} \mathrm{O}_{3}(\text { ileum } / \text { feces }) \times \text { nutrient }(\text { diet })}\right] \times 100
\end{aligned}
$$

where nutrient digestibility is apparent digestibility of a nutrient or energy in the diet (\%); nutrient (diet) and nutrient (ileum/feces) is a nutrient (g) or energy ( $\mathrm{kcal} / \mathrm{kg} \mathrm{DM})$ concentration in the diet and the ileal/feces samples, respectively; $\mathrm{Cr}_{2} \mathrm{O}_{3}$ (diet) and $\mathrm{Cr}_{2} \mathrm{O}_{3}$ (ileum) are the $\mathrm{Cr}_{2} \mathrm{O}_{3}$ concentration $(\mathrm{g} / \mathrm{kg})$ in the diet and the ileal or feces samples, respectively.

Blood characteristics: Blood samples from two pigs per pen were collected via neck-internal jugular vein using sterile needle before morning feeding on $\mathrm{d} 14$ and $\mathrm{d} 35$. At each collection time, $4 \mathrm{~mL}$ of blood from each pig were collected into both $\mathrm{K}_{2}$ ethylenediaminetetraacetic acid (EDTA) and serum tubes (Zhejiang Gongdong Medical Technology Co. Ltd, Zhejiang, China). The blood samples were kept in suitable ice-box and transported from the farm to analytical laboratory for maximum 60 minutes delay. The blood collection in EDTA tubes were automatically analyzed using hematology analyzer ABX Pentra DX 120c in order to determine red blood cell (RBC) and white blood cell (WBC) counts, hemoglobin $(\mathrm{Hb})$, lymphocytes percentage. The blood collection serum tubes were centrifuged for 15 minutes in a bench centrifuge at 3,000 rpm, and then clean serum was 
collected and stored at $4^{\circ} \mathrm{C}$ until further analysis. The serum samples were analyzed using Cobas 8000 modular analyzer series (Roche-Hitachi, Tokyo, Japan) in order to determine biochemistry and immunology parameters including albumin, globulin, immunoglobulin $\mathrm{G}(\mathrm{IgG})$, and IgM.

Gut microbial composition: i) Colonic digesta samples: colonic samples of 48 piglets were individually harvested after slaughter, in which 8 animals per diet on d 14 and d 35. Individual two samples of each colonic digesta were separately collected in sterile tubes (PSP Spin Stool DNA Plus Kit, Berlin, Germany), and stored at $-80^{\circ} \mathrm{C}$ until further DNA extraction.

ii) DNA extraction and purification: Genomic DNA was extracted and purified from colonic digesta samples using PSP Spin Stool DNA Plus Kit (STRATEC Molecular GmnH, Berlin, Germany) following the manufacturer's recommendations. The integrity of DNA was tested by $1 \%$ agarose gel electrophoresis. DNA concentrations were measured by absorbance at $260 \mathrm{~nm}$ and its purity was estimated by determining the A260/A280 ratio with using Eppendorf BioSpectrometer basic (Hamburg, Germany). Genomic DNAs were stored at $-20^{\circ} \mathrm{C}$, and then transported to University of Liège (Belgium) for $16 \mathrm{~S}$ ribosomal RNA (rRNA) sequencing.

iii) $16 \mathrm{~S}$ rRNA gene library construction and sequencing: The $16 \mathrm{~S}$ polymerase chain reaction (PCR) libraries were generated for samples. PCR-amplification of the V1-V3 hypervariable region of bacterial $16 \mathrm{~S}$ rRNA were performed using following primers (with Illumina overhand adapters), forward (5'-GAGAGTTTGATYMTGGCTCAG-3') and reverse (5'ACCGCGGCTGCTGGCAC-3'). Each PCR product was purified with Agencourt AMPure XP beads kit (Beckman Coulter, Pasadena, CA, USA) and submitted to a second PCR round for indexing, using Nextera XT index primers 1 and 2. After purification, PCR products were quantified using Quant-IT PicoGreen (ThermoFisher Scientific, Waltham, MA, USA) and diluted to $10 \mathrm{ng} / \mu \mathrm{L}$. A final quantification, by quantitative PCR (qPCR), of each sample in the library was performed using KAPA SYBR FAST qPCR Kit (KapaBiosystems, Wilmington, MA, USA) before normalization, pooling and sequencing on a MiSeq sequencer using v3 reagents (Illumina, San Diego, CA, USA). Positive control using DNA from 20 defined bacterial species and a negative control (from the PCR step) were included in sequencing run.

Sequence reads processing was used as described previously [18] using MOTHUR software package v1.39.5 [19], and VSEARCH algorithm [20] respectively for alignment and clustering and chimera detection. Clustering distance of 0.03 was used for operational taxonomic unit (OTU) generation; $16 \mathrm{~S}$ reference alignment and taxonomical assignation were based upon the SILVA database (v1.28) of full-length $16 \mathrm{~S}$ rRNA sequences [21]. From 4,553,186 raw reads (16 samples per diet, 2 periods included d 14 and d 35, 3 diets), we obtained
$3,769,161$ reads after cleaning (length and sequence quality) and 3,337,068 after chimeric contaminants elimination. We retained 5,000 reads per sample as a subsampling process for OTU clustering and taxonomic assignment. Good's coverage estimator was used as a measure of sampling effort for each sample, with a mean value of $99.70 \%$.

Subsample datasets were used to assess alpha diversity using Reciprocal Simpson biodiversity index (diversity), Chaol richness index (richness), and Simpson evenness index (evenness) at the genus level using MOTHUR. Beta diversity was assessed with MOTHUR using distance matrices based on Bray-Curtis dissimilarity index (a measure of community structure that considers shared OTUs and their relative abundances) and non-metric dimensional scaling, based upon the Bray-Curtis dissimilarity matrix was applied to visualize the biodiversity between the groups. Analysis of molecular variance test with 100,000 permutations was performed to assess the diversity clustering of treatment diets with Bray Curtis matrix using MOTHUR [22]. Ordination analysis and $3 \mathrm{~d}$ plots were performed with Vegan [23], Vegan3d [24] and rgl [25] packages in $\mathrm{R}$ [26].

All biosample raw reads of colonic digesta samples have been deposited at the National Center for Biotechnology Information (NCBI) and are available under the Bioproject ID PRJNA428433.

\section{Chemical analysis}

The $\mathrm{DM}$ of $\mathrm{RDP}$, diets, and digesta isolated from ileum were dried by oven drying at $70^{\circ} \mathrm{C}$ for $15 \mathrm{~h}, 90^{\circ} \mathrm{C}$ for $5 \mathrm{~h}$ and $102^{\circ} \mathrm{C}$ for $5 \mathrm{~h}$ consecutively, and they were milled separately through a $1 \mathrm{~mm}$ screen prior to analysis. The DM of feed ingredient was determined according to Method 934.01 from AOAC [27]. Feed ingredients and diets were analyzed for CP (Method 954.01, AOAC, 1990), ether extract (EE; Method 920.39, AOAC, 1990) with petroleum ether solvent, ash (Method 942.05, AOAC, 1990), crude fiber (CF; Method 962.09, AOAC, 1990), neutral detergent fiber and acid detergent fiber (ADF) (Method 973.18, AOAC, 1990) with fiber filter bags of Ankom technology F57, phosphorus (P; Method 965.17, AOAC, 1990) using a UV-vis spectrophotometer. Calcium (Ca) was determined by titration with a standardized solution of EDTA as previously described [28], and starch was determined from estimation of reducing sugars by dinitrosalicylic acid method under spectrophotometer UV-1800 (Kyoto, Japan) as previously described [29]. Chromium was analyzed using UV absorption spectrophotometry (UV-1800, Japan) according to [30]. The GE of samples were measured using a bomb calorimeter $\mathrm{E} 2 \mathrm{~K}$ (Germany). The $\mathrm{pH}$ value of $\mathrm{RDP}$ was determined using an electrode of a portable $\mathrm{pH}$ meter (HANNA, Singapore). Organic acids (OA) were determined by Vinger method (Ngoan, 2002). Ethanol in RDP was determined using high performance liquid chromatography (Agilen 1200 series; 
Agilent Technologies, Santa Clara, CA, USA) with Aminex HPX-87H column, RI detector, phase mobile including $\mathrm{H}_{2} \mathrm{SO}_{4}$ $10 \mathrm{mM}$; mobile phase flow rate was $0.5 \mathrm{~mL} / \mathrm{min}$, the column temperature was maintained at $60^{\circ} \mathrm{C}$.

\section{Statistical analysis}

Data for growth performance and blood profiles were analyzed using the PROC MIXED procedure of SAS software (Version 9.4, Institute Inc., Cary, NC, USA). The statistical model included the diets $(n=3)$ as fixed effect, and the blocks $(n=4)$ as random effects. Pen was used as experimental unit for the performance data, and individual pig as experimental unit for visceral organ weights, gut $\mathrm{pH}$ and blood profiles. For repeated measures performed on the same experimental unit a similar model was used but including the effect of a compound symmetry structure of covariance. Orthogonal polynomials were performed to determine linear and quadratic effects of increasing level of the RDP in diets [31]. Data for pigs fed diets containing RDP were compared with data for pigs fed control diet using orthogonal contrasts. The multiple comparisons of least square means were performed according to PDIFF option. Significance was defined as $\mathrm{p}<$ 0.05 and $0.05<\mathrm{p}<0.10$ was considered as a trend. Due to unintentional feces and digesta pooling by diet, no statistical analysis could be performed on digestibility data.

Data for microbiota composition in the colon, the statistical differences in bacterial diversity, bacterial richness and bacterial evenness between pig fed control diet and diets containing RDP were performed using Kruskal-Wallis with Benjamini, Krieger, and Yekutieli test (PRISM 7.0, Graph-Pad software, La Jolla, CA, USA). Beta diversity (Bray-Curtis dissimilarity) was compared using Kruskal-Wallis with Bonferroni correction $(\mathrm{p} \leq 0.003)$. To compare statistical differences in bacterial community abundance between diets, a nonparametric Kruskal-Wallis $\mathrm{H}$ tests was combined to a Storey False Discovery Rate followed by Tukey-Kramer post-hoc test (using STAMP 2.1.3 software) as previously described [32]. The significant level used for statistical tests was 0.05 .

\section{RESULTS}

\section{Animal performance, visceral organ weight, $\mathrm{pH}$ value of digestive tract and digestibility}

With inclusion levels of RDP, a linear trend ( $p=0.07)$ for increasing ADG was observed in the two experimental periods, and FCR tended to decrease in the second one $(\mathrm{p}=0.08)$ (Table 2). Final body weight (FBW) at d 35 thus increased linearly with dietary RDP inclusion. Besides, using orthogonal contrasts, increase in FBW was observed $(\mathrm{p}<0.05)$ when pigs fed RDP diets were compared with control pigs. As a rule, no significant differences in visceral organ weights were observed between groups, but heart weight at $\mathrm{d} 14$ and empty stomach weight at d 35 were negatively and positively impacted, respectively, by RDP level $(\mathrm{p}=0.04$ and $\mathrm{p}=0.03)$ (Table 3). With level of RDP incorporation, weights of visceral organs-except gut-relative to live weight decreased on $\mathrm{d} 14$ so far that their sum decreased by 4.4 and $11.6 \%$, in RDP15 and RDP30, respectively, when compared to the control group.

When regard to $\mathrm{pH}$ values of stomach, ileum, caecum and colon contents, no differences between groups were observed at both $\mathrm{d} 14$ and $\mathrm{d} 35$. However, the $\mathrm{pH}$ values decreased nu-

Table 2. Dry mater intake, average daily gain, and feed conversion ratio (LSM) of piglets fed diets containing different levels of rice distillers' by-product

\begin{tabular}{|c|c|c|c|c|c|c|}
\hline \multirow{2}{*}{ Items } & \multicolumn{3}{|c|}{ Treatment ${ }^{1)}$} & \multirow{2}{*}{ SEM } & \multicolumn{2}{|c|}{ p-value } \\
\hline & RDPO & RDP15 & RDP30 & & Linear & Quadratic \\
\hline \multicolumn{7}{|l|}{ d 0 to $d 14$} \\
\hline $\mathrm{IBW}(\mathrm{kg})$ & 7.55 & 7.53 & 7.53 & 0.51 & 0.87 & 0.96 \\
\hline FBW (kg) & 10.2 & 10.4 & 10.5 & 0.61 & 0.23 & 0.84 \\
\hline $\mathrm{DMI}(\mathrm{g} / \mathrm{d})$ & 402 & 401 & 399 & 30.6 & 0.18 & 0.59 \\
\hline FCR $(\mathrm{kg} / \mathrm{kg})$ & 2.14 & 1.94 & 2.10 & 0.14 & 0.80 & 0.25 \\
\hline \multicolumn{7}{|l|}{ d 15 to $d 35$} \\
\hline Number of animals & 8 & 8 & 8 & & & \\
\hline $\mathrm{IBW}(\mathrm{kg})$ & 10.2 & 10.5 & 10.6 & 0.54 & 0.36 & 0.86 \\
\hline FBW (kg) & 19.0 & 20.0 & 20.9 & 0.71 & 0.01 & 0.98 \\
\hline DMI (g/d) & 723 & 722 & 724 & 35.4 & 0.42 & 0.35 \\
\hline
\end{tabular}

LSM, least squares means; SEM, standard error of the mean; d, day; IBW, initial body weight; FBW, final body weight; ADG, average daily gain; DMI, daily dry matter intake; FCR, feed conversion ratio (kg DM feed/kg gain); DM, dry matter.

1) RDP0, control diet; RDP15, diet with rice distillers' by-product accounting for 15\% DM; RDP30, diet with rice distillers' by-product accounting for $30 \%$ DM. 
Table 3. Visceral organ weight (LMS) of piglets fed diets containing different levels of rice distillers' by-product

\begin{tabular}{|c|c|c|c|c|c|c|}
\hline \multirow{2}{*}{ Items } & \multicolumn{3}{|c|}{ Dietary treatment ${ }^{1)}$} & \multirow{2}{*}{ SEM } & \multicolumn{2}{|c|}{ p-value } \\
\hline & RDPO & RDP15 & RDP30 & & Linear & Quadratic \\
\hline \multicolumn{7}{|l|}{ Organ weight (g) on d 14} \\
\hline Heart & 55.6 & 49.9 & 48.2 & 3.58 & 0.04 & 0.50 \\
\hline Kidney & 62.3 & 62.1 & 54.8 & 4.22 & 0.16 & 0.96 \\
\hline Liver & 235 & 226 & 217 & 9.12 & 0.16 & 0.96 \\
\hline Lung & 127 & 130 & 115 & 11.6 & 0.32 & 0.41 \\
\hline Spleen & 18.1 & 17.6 & 18.2 & 1.81 & 0.95 & 0.75 \\
\hline Empty stomach & 75.7 & 81.2 & 81.6 & 4.78 & 0.32 & 0.61 \\
\hline Empty small intestine & 400 & 411 & 396 & 26.5 & 0.92 & 0.68 \\
\hline Empty large intestine & 126 & 112 & 138 & 13.7 & 0.46 & 0.18 \\
\hline \multicolumn{7}{|l|}{ Organ weight (g) on d 35} \\
\hline Heart & 80.1 & 81.2 & 83.9 & 7.39 & 0.62 & 0.91 \\
\hline Kidney & 83.8 & 79.9 & 82.5 & 7.02 & 0.84 & 0.57 \\
\hline Liver & 372 & 377 & 382 & 24.7 & 0.67 & 0.98 \\
\hline Lung & 176 & 174 & 172 & 11.4 & 0.79 & 0.99 \\
\hline Spleen & 25.4 & 27.3 & 26.3 & 2.33 & 0.72 & 0.50 \\
\hline Empty stomach & 124 & 133 & 148 & 7.08 & 0.03 & 0.70 \\
\hline Empty small intestine & 671 & 638 & 652 & 49.4 & 0.65 & 0.53 \\
\hline Empty large intestine & 225 & 216 & 245 & 25.8 & 0.41 & 0.38 \\
\hline
\end{tabular}

LSM, least squares means; SEM, standard error of the mean; $d$, day; DM, dry matter.

1) RDP0, control diet; RDP15, diet with rice distillers' by-product accounting for 15\% DM; RDP30, diet with rice distillers' by-product accounting for $30 \%$ DM.

merically in all segments at $\mathrm{d} 14$ when increasing inclusion of RDP in diet (Table 4).

The AID and ATTD of CP, lipids, and gross energy numerically decrease with inclusion of RDP, especially for energy and lipids (Figure 1).

\section{Physical and chemical properties of the blood}

On d 14, a linear decrease in amount of globulin was observed $(\mathrm{p}=0.003)$ in pigs fed RDP diets when compared with pigs fed control diet. Quadratic effects were observed $(\mathrm{p} \leq 0.04)$ for WBC, lymphocyte, and albumin. On d 35, a trend for linear effect for RBC ( $\mathrm{p}=0.06)$ and a trend for quadratic effect for $\mathrm{Hb}(\mathrm{p}=0.09)$ were observed between diet groups. Other hematological parameters were not affect by pigs fed RDP diets compared with pigs fed control diet (Table 5).

\section{Colonic microbiome analysis by $16 \mathrm{~S}$ rRNA profiling}

The analysis of alpha diversity of colonic bacterial population showed that no statistical differences were found $(\mathrm{p}>0.05)$ between weaned pigs fed RDP diets and pigs fed control diet within the same period, as estimated by diversity indices including reciprocal Simpson Biodiversity, Chaol richness, and

Table 4. pH values (LSM) of stomach, ileum, caecum, and colon digesta of piglets fed diets containing different levels of rice distillers' by-product

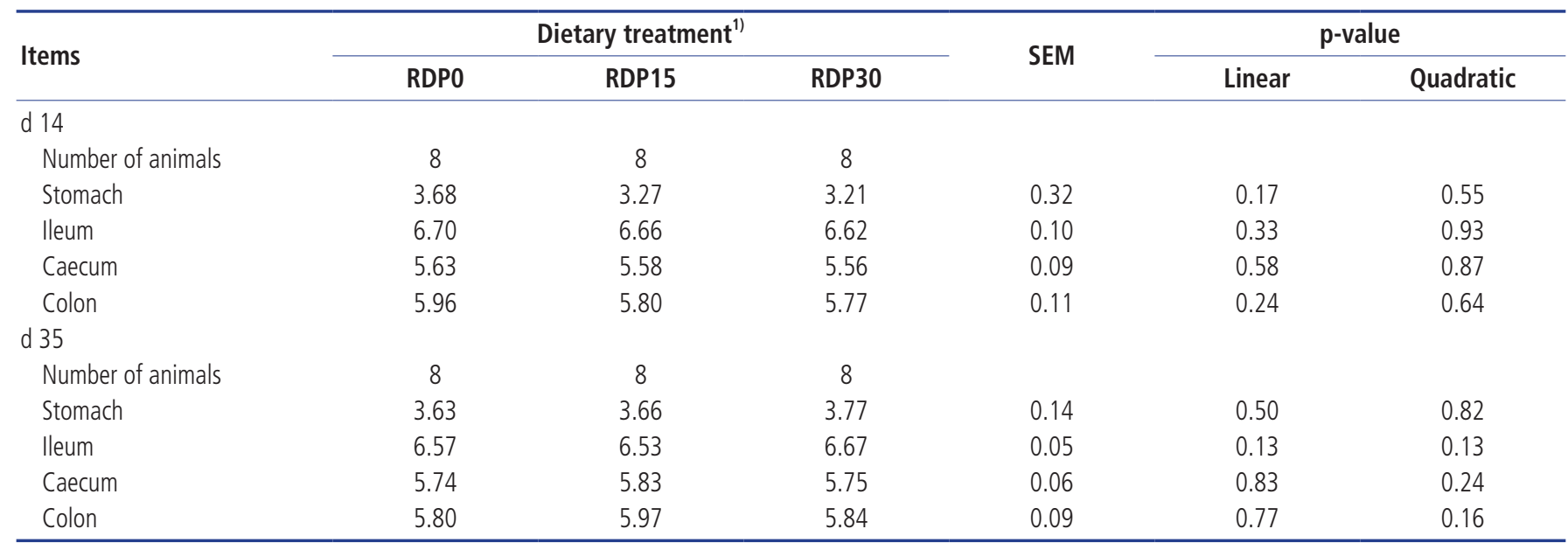

LSM, least squares means; SEM, standard error of the mean; $d$, day; DM, dry matter.

1) RDPO, control diet; RDP15, diet with rice distillers' by-product accounting for 15\% DM; RDP30, diet with rice distillers' by-product accounting for $30 \%$ DM. 

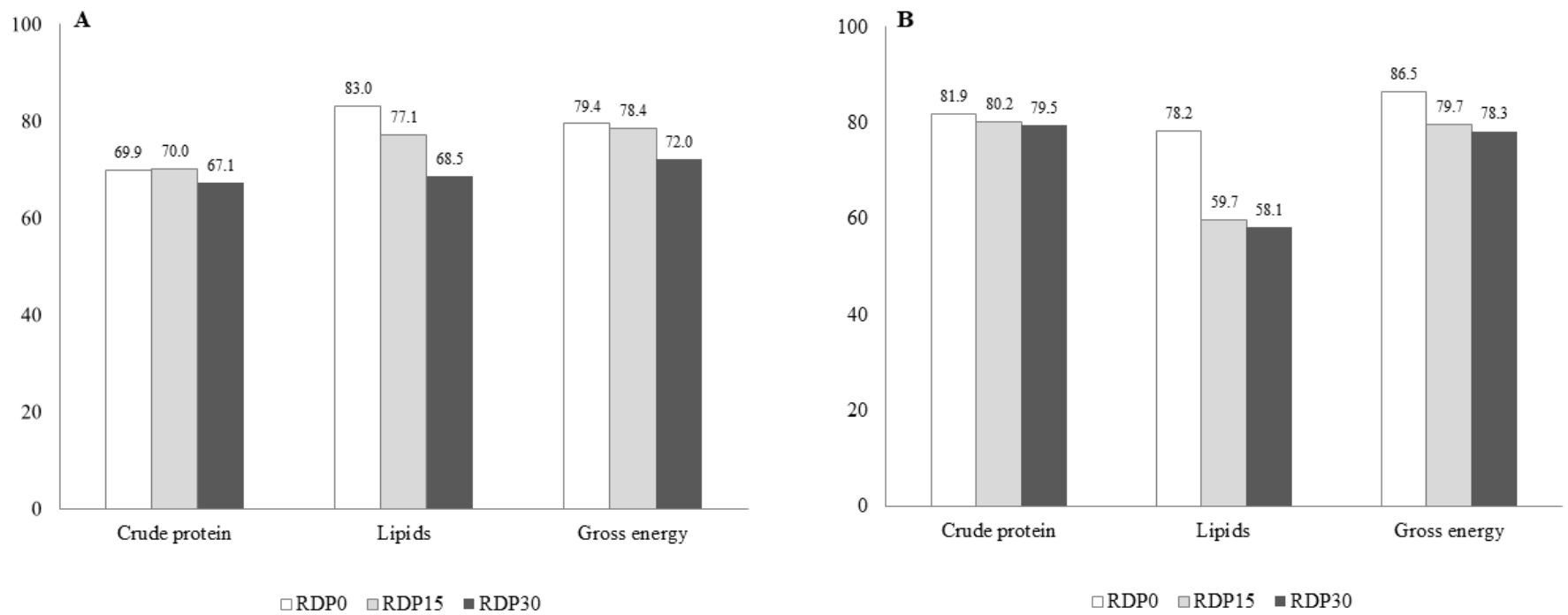

Figure 1. Coefficients of apparent ileal digestibility (AID) (A) and of apparent total tract digestibility (ATTD) (B) of weaned pigs fed diets containing different levels of rice distillers' by-product. RDP0, control diet; RDP15, diet with rice distillers' by-product accounting for 15\% dry mater; RDP30: diet with rice distillers' by-product accounting for $30 \%$ dry mater.

Table 5. Parameters of biochemistry, hematology, and immunology (LSM) of piglets fed diets containing different levels of rice distillers' by-product

\begin{tabular}{|c|c|c|c|c|c|c|}
\hline \multirow{2}{*}{ Items } & \multicolumn{3}{|c|}{ Dietary treatment ${ }^{1)}$} & \multirow{2}{*}{ SEM } & \multicolumn{2}{|c|}{$p$-value } \\
\hline & RDPO & RDP15 & RDP30 & & Linear & Quadratic \\
\hline \multicolumn{7}{|l|}{ d 14} \\
\hline Number of animal & 8 & 8 & 8 & - & - & - \\
\hline WBC (Giga/L) & 17.5 & 20.6 & 17.6 & 1.39 & 0.94 & 0.04 \\
\hline RBC (Tera/L) & 5.59 & 5.64 & 5.94 & 0.25 & 0.34 & 0.70 \\
\hline $\mathrm{Hb}(\mathrm{g} / \mathrm{dL})$ & 10.6 & 10.5 & 11.1 & 0.32 & 0.27 & 0.36 \\
\hline Lymphocyte (\%) & 50.7 & 44.9 & 54.2 & 2.78 & 0.25 & 0.01 \\
\hline Albumin (ALB, g/L) & 30.0 & 27.8 & 30.8 & 1.41 & 0.42 & 0.01 \\
\hline Globulin (g/L) & 14.9 & 13.3 & 10.4 & 0.96 & 0.003 & 0.54 \\
\hline $\operatorname{lgG}(\mathrm{mg} / \mathrm{dL})$ & 242 & 233 & 235 & 14.7 & 0.66 & 0.67 \\
\hline $\operatorname{lgM}(\mathrm{mg} / \mathrm{dL})$ & 38.4 & 46.1 & 40.6 & 7.11 & 0.82 & 0.41 \\
\hline \multicolumn{7}{|l|}{ d 35} \\
\hline Number of animal & 4 & 4 & 4 & - & - & - \\
\hline WBC (Giga/L) & 22.0 & 19.2 & 19.0 & 2.71 & 0.46 & 0.71 \\
\hline RBC (Tera/L) & 6.67 & 6.73 & 6.23 & 0.27 & 0.06 & 0.16 \\
\hline $\mathrm{Hb}(\mathrm{g} / \mathrm{dL})$ & 11.9 & 12.1 & 11.5 & 0.31 & 0.18 & 0.09 \\
\hline Lymphocyte (\%) & 42.8 & 46.4 & 49.8 & 5.11 & 0.37 & 0.99 \\
\hline Albumin $(A L B, g / L)$ & 28.5 & 26.7 & 27.9 & 1.72 & 0.76 & 0.34 \\
\hline Globulin (g/L) & 16.8 & 18.2 & 16.8 & 0.74 & 1.00 & 0.17 \\
\hline $\operatorname{lgG}(\mathrm{mg} / \mathrm{dL})$ & 85.5 & 88.1 & 85.7 & 3.63 & 0.98 & 0.60 \\
\hline $\operatorname{lgM}(\mathrm{mg} / \mathrm{dL})$ & 35.1 & 41.7 & 35.5 & 6.62 & 0.96 & 0.43 \\
\hline
\end{tabular}

LSM, least squares means; SEM, standard error of the mean; WBC, white blood cell count; RBC, red blood cell count; Hb, hemoglobin; Ig, immunoglobulin; d, day; DM, dry matter.

1) RDP0, control diet; RDP15, diet with rice distillers' by-product accounting for 15\% DM; RDP30, diet with rice distillers' by-product accounting for $30 \%$ DM.

Simpson Evenness (Figure 2). However, bacterial richness of colonic microbiota was greater in RDP30 on $\mathrm{d} 35$ than on $\mathrm{d}$ $14(\mathrm{p}=0.01)$. Beta diversity differed between diet groups as indicated by clear clustering on principal coordinates of microbial profiles on d 14 and d 35. Indeed, colonic microbiota communities differed between RDP0 and RDP30 on d 14 and $\mathrm{d} 35(\mathrm{p}=0.002$, and $\mathrm{p}<0.001)$, and between RDP15 and $\mathrm{RDP} 30$ on $\mathrm{d} 35(\mathrm{p}=0.002)$.

Differences in colonic bacterial compositions at taxonomic levels (family and genus) are presented in Figure 3 and 4. When comparing relative abundance of family of diets in a contemporary, proportion of Lachnospiraceae in RDP30 was 
Species Diversity

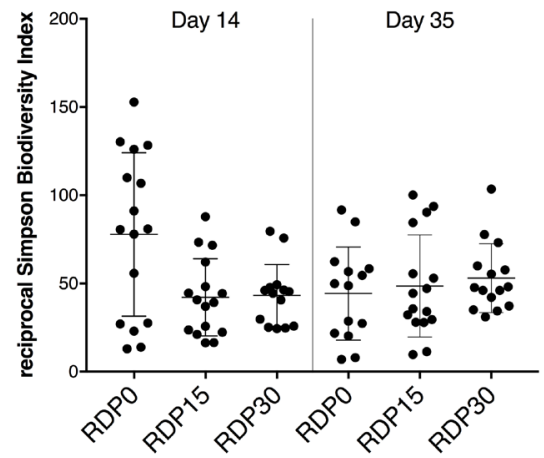

Species Richness

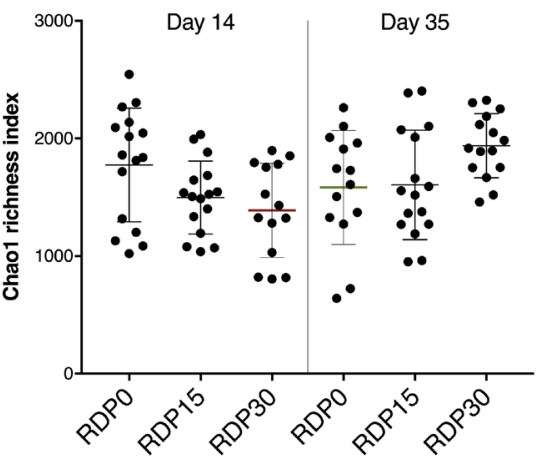

Species Evenness

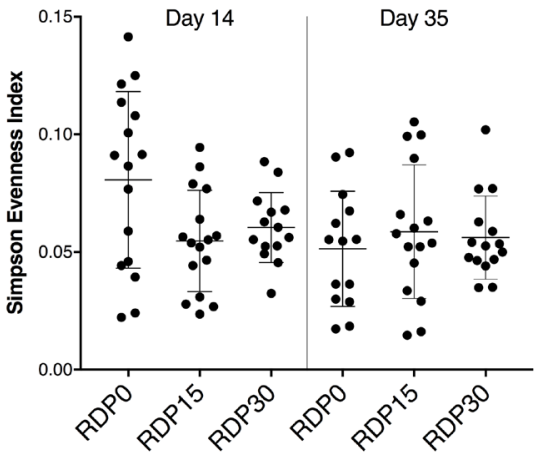

Figure 2. Alpha diversity comparisons for colon composition of weaned piglets fed rice distillers' by-product levels on d 14 and d 35 detected by $16 \mathrm{~S}$ rRNA gene metagenetic analysis.

lower on $\mathrm{d} 14(\mathrm{p}=0.002)$ and greater on d $35(\mathrm{p}<0.001)$. Proportion of Ruminococcaceae was greater in RDP0 ( $\mathrm{p}<0.001)$ on d 14, whilst greater in RDP30 on d 35 ( $\mathrm{p} \leq 0.03$ ). Proportion of Bacteroidales_fa was lower in RDP15 on d 14 ( $\mathrm{p} \leq 0.04)$, and greater in RDP30 ( $\mathrm{p}<0.001)$ on d 35. And proportion of Prevotellaceae increased $(\mathrm{p} \leq 0.01)$ on 14 and decreased $(\mathrm{p} \leq 0.05)$ on d 35 according to inclusion levels of RDP (Supplementary Table S1).

When comparing relative abundance of genus of diets in a contemporary, Lachnospiraceae_ge in RDP30 was respectively lower $(p=0.008)$ and greater $(p<0.001)$ on $d 14$ and $\mathrm{d} 35$. Ruminococcaceae spp. was greater in RDP0 on d 14, while greater in RDP30 on d $35(\mathrm{p}<0.001)$. Bacteroidales was lower in RDP15 on d 14 ( $\mathrm{p} \leq 0.002)$, whilst greater in RDP30 on $\mathrm{d} 35$ ( $\mathrm{p}<0.001)$. Prevotellaceae increased with inclusion of RDP on both d 14 and d $35(\mathrm{p}<0.001)$. Prevotellaceae NK3B31_group was greater in RDP15 on $\mathrm{d} 14(\mathrm{p} \leq 0.001)$ and in RDP30 on d 35 ( $<<0.001)$. Prevotella_1 was lower in DAR15

\section{Family}

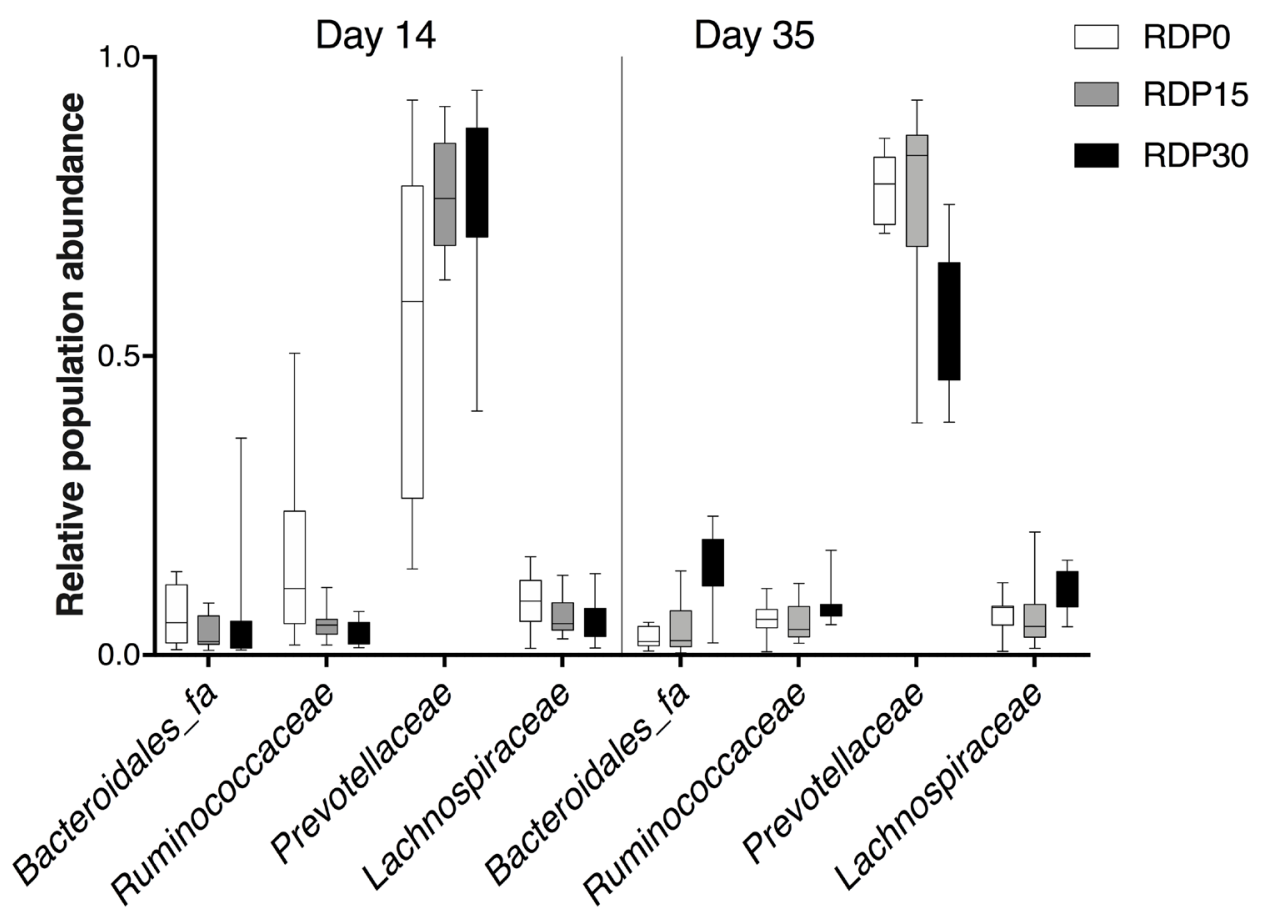

Figure 3. Differences in relative abundance at the family level of colonic microbiota of weaned pigs fed diets containing different levels of rice distiller' by-product on d 14 and d 35 detected by 165 rRNA gene metagenetic analysis. RDP0, control diet; RDP15, diet with rice distillers' by-product at 15\% dry matter; RDP30, diet with rice distillers' by-product at $30 \%$ dry matter. 


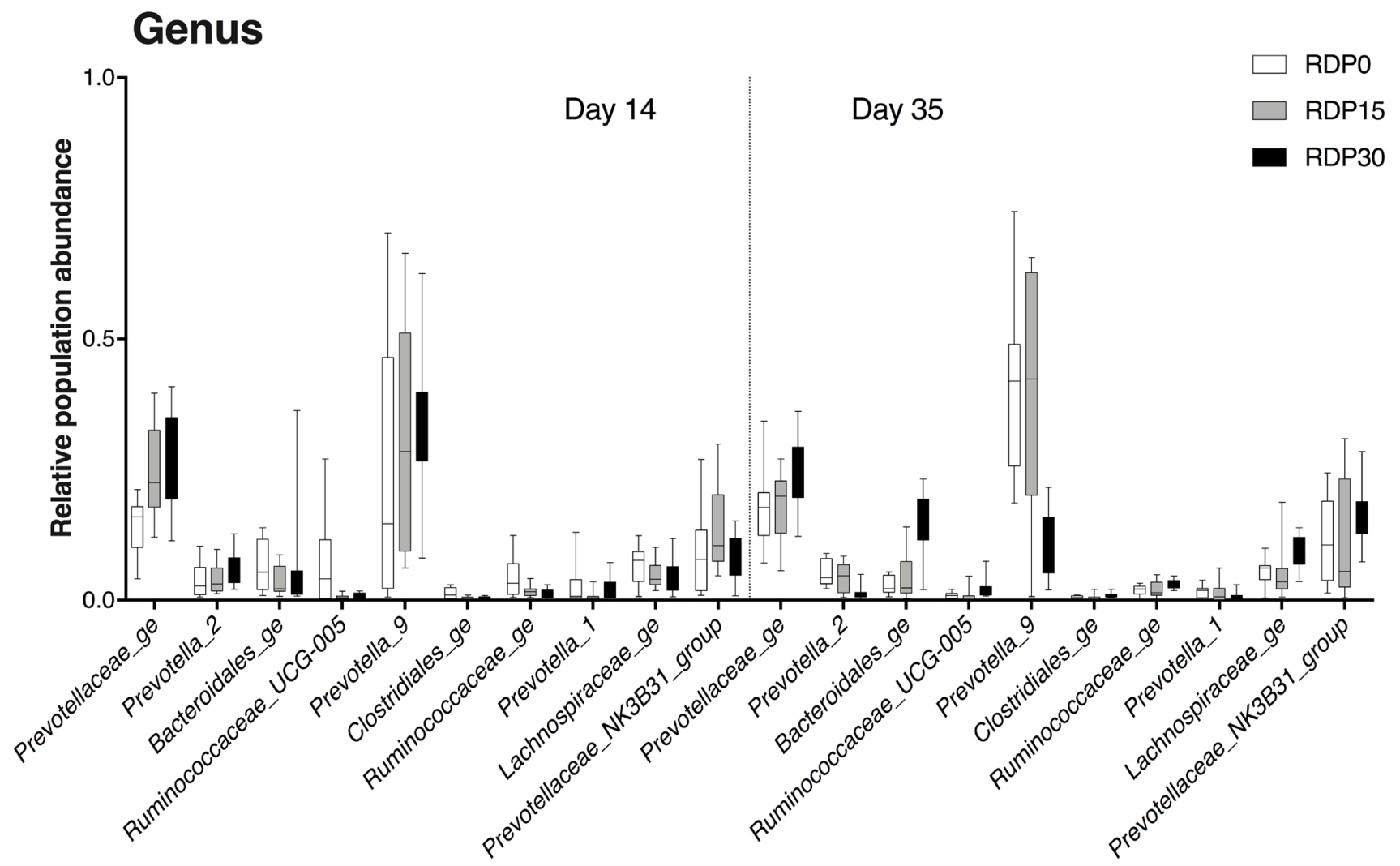

Figure 4. Differences in relative abundances at the genus level of colonic microbiota of weaned pigs fed diets containing different levels of rice distiller' by-product on d 14 and d 35 detected by 16S rRNA gene metagenetic analysis. RDP0, control diet; RDP15, diet with rice distillers' by-product at 15\% dry matter; RDP30: diet with rice distillers' by-product at $30 \%$ dry matter.

on d 14 ( $\mathrm{p} \leq 0.02)$. Increases in Prevotella_2 and Prevotella_9 on $\mathrm{d} 14(\mathrm{p} \leq 0.04)$ and an inverse tendency on $\mathrm{d} 35(\mathrm{p}<0.001)$ were found with inclusion level of RDP (Supplementary Table S2).

\section{DISCUSSION}

\section{Chemical composition of the diets}

Rice by-products classically are incorporated in diets for pig in Asia. Thus, one could argue some confounding effects between RDP levels and the other rice ingredients of the diets. Confounding bias cannot be completely avoided in such experiments. The main constraint aimed to preserve iso-nitrogenous characteristics of the diets. The RDP showed a high CP level, this constraint only could be fulfilled thanks to decreases in soybean by-products levels. With CF content close to $0.35 \%$, broken rice could be considered to maintain similar levels of starch between the groups. Rice bran helped to compensate for $\mathrm{CF}$ provided by RDP. In this context, it should be kept in mind that the level of RDP incorporation in the diets was the main — and thus not the exclusive-factor of variation.
Animal performance, visceral organ weight, and $\mathrm{pH}$ value of digestive tract

In the first three days of the experiment, loose feces appeared on some experimental pens due to digestive disorders, this phenomenon resolved few days after feed intake amount was reduced. Therefore, diarrhea in piglets was not evaluated during the entire experimental period. All piglets in our experiment remained in good health, probably due to a good set-up with clean environment during the experimental period. Increasing inclusion level of RDP did not affect DM intake, and tended to improve ADG during $\mathrm{d} 0$ to $\mathrm{d} 14$ and $\mathrm{d} 15$ to $\mathrm{d} 35$, leading to higher final live weights in animals fed RDP. Interestingly, feed efficiency was improved only from $\mathrm{d} 15$ to $\mathrm{d} 35$. According to earlier studies, piglets fed diets with $10 \%, 15 \%, 20 \%$, and 30\% RDP had enhanced ADG and FCR compared with piglets fed control diet, but without effect in DM intake during a 42-d experiment $[2,13]$, suggesting that $\mathrm{RDP}$ does not affect diet palatability in weaned pigs. Lower $\mathrm{pH}$ and higher lactic and acetic contents in RDP product could be beneficial to the gut health of piglets through a decrease in number of harmful bacteria such as Escherichia coli and total coliforms, and an increase in number of beneficial bacteria such as lactic acid bacteria [13]. This has been shown 
for pigs fed fermented diets [13,33]. In addition, short chain OA, mainly acetate, propionate, butyrate and lactate are produced in large intestine by fermentation of undigested protein and fiber fractions. These OA had deep effects on metabolism and gut health [34]. Acetate and propionate are energy substrates for lipogenesis and gluconeogenesis, respectively, and butyrate is used primarily by colonocytes as major energy source for their metabolic activities in pigs [35-38]. Hong et al [13] demonstrated that the concentrations of acetic acid and lactic acid in colonic digesta were greater for piglets fed RDP diet than those fed diet without RDP. Thus, our results suggest that the positive effect on growth performance of weaned piglets fed RDP diets may be associated with modulation of OA-production bacteria due to various diet components. In addition, no differences in almost all visceral organ weights among diet groups was observed. This is similar to previous report from [6] who demonstrated that there were no differences in heart, lung, liver, spleen, stomach, kidney, small intestine, and large intestine weights in growing pigs fed diets with different inclusion levels of RDP ( $0 \%, 7.5 \%, 15 \%, 22.5 \%$, $30 \% \mathrm{DM})$. However, an increase in relative weight of empty stomach on d 35 was found with RDP diets, which could be due to soluble fiber content of RDP originated from glutinous rice [39] leading to increase in transit time of diets [40] from stomach to intestine. This could increase digestive fluids secretion and activity for breaking down feed that resulted in stomach enlargement [41]. Lower heart weight of pigs fed $\mathrm{RDP}$ diets on only d 14 is unclear and possibly due to fortuitous statistical significance but the more than $4 \%$ to $11 \%$ numerical decreases of the overall visceral-but stomach and intestines-proportions of live weight is noticeable. Such decreases suggest a more efficient viscera metabolism, may be consecutive to ready-to-use metabolites stemming from fiber fermentation, reducing thus metabolic burden for these organs. This hypothesis would merit to be further investigated.

\section{Digestibility}

Recent study [13] reported that a greater AID and a similar ATTD of CP was found for weaned pigs fed diet with $20 \%$ $\mathrm{RDP}$ than pigs fed control diet for a 42 -d experiment. Moreover, piglets fed pectin-containing diet showed higher digesta viscosity with decrease ileal digestibility of protein [42]. Thus, and in the limit of variance indicators failure, the numerical decrease in AID and ATTD of CP in RDP diets could be related to high pectin content. The decrease in ATTD of CP with $\mathrm{RDP}$ inclusion could indicate a partial nitrogen flux shift from plasma (urea) to hindgut lumen, thanks to nitrogen conversion to microbial protein, the one thereafter excreted in feces. Additionally, a decrease in AID and ATTD of EE with inclusion of RDP, as observed in this study, has never been reported. According to [43] piglet diets supplemented with pectin could have negative effect on fat digestibility. A other study [44] revealed that weaning pigs fed diets containing OA had changed intestinal microbiota composition, with decreased amount of bile acid production, thus leading to negative impact on fat digestion. The OA issued from RDP diets possibly contributed to alter EE CATTD.

\section{Physical and chemical properties of the blood}

Effect of RDP incorporation in weaned pig diet on blood profiles has not been published yet. This study found no effect of $\mathrm{RDP}$ on hematological profiles such as WBC, Hb, and lymphocyte percentage, and biochemical parameters such as serum concentrations of albumin, IgG, and IgM, except serum globulin concentration on $\mathrm{d} 14$ and $\mathrm{RBC}$ count on $\mathrm{d} 35$. Despite decreased $\mathrm{RBC}$ and globulin values with inclusion of RDP, all results were found to be within the normal ranges for weaned pigs, as reported previously [45-48]. The difference in values over time were considered as normal owing to the pig developmental stage [40]. Additionally, according to [44], $\operatorname{IgA}$, IgG, and IgM concentrations were not influenced by supplementation of $\mathrm{OA}$ in weaning piglet diets, which in line with our results. The largest immunologically competent organ in the body is gut or its associated lymphoid system, and the development of immune system is associated with composition of indigenous micro flora [49]. With inclusion of $\mathrm{RDP}$, the decrease in serum globulin concentration on $\mathrm{d} 14$ and of RBC count on d 34 was not clear and could be due to stochastic or incidental effects without relationships with RDP. Further studies are required to drain more conclusion.

\section{Colonic microbiome analysis by $16 \mathrm{~S}$ rRNA profiling}

Intestinal microbiota, that affect nutrient metabolism and immune system development, play a significant role in intestine and host health of pigs [50]. Gut microbiota composition is affected by diet composition, in particular fiber components [51]. In this study, we compared the microbial population structure and microbiota composition from colonic digesta of the weaned pigs. To the best of our knowledge, this is the first report to evaluate the effect of RDP inclusion on the colonic microbiota of weaned pigs using 16S rRNA gene sequence analysis. On d 35, colonic microbial richness increased in piglets fed RDP30 in the later phase of feeding trial, suggesting that inclusion of $30 \%$ RDP may stimulate the growth of colonic bacteria in a long-term intervention. Moreover, beta diversity analysis indicated different clustering of microbial community structure between RDP diets and control diet. In addition, the microbial compositions significantly varied with inclusion of RDP at family and genus levels. The change in relative abundance of colonic microbiota composition could be related to the chemical components of RDP, especially fiber fraction. Most of the time, the composition of bacterial communities in colonic contents presented opposite 
evolution when comparing d 14 and d 35 values. This could due to an adaption phase of immature digestive tract of weaned piglets. An increase in relative abundance of Prevotellaceae NK3B31_group was found in pigs fed diets containing high component of arabinoxylan on d 28 [52], which also was found in our results. Besides that, a considerable decrease in Prevotella_1, Prevotella_2, and Prevotella_9 proportions was observed in piglets fed RDP30 on d 35 . The reason for this variation might be associated with increased microbiota compositions of Prevotellaceae_ge, Prevotellaceae_NK3B31_ group. Indeed, arabinoxylan fiber, an important content of plan cell walls of rice, is considered as a prebiotic effect on intestinal health of pigs stimulating the growth of the latter bacteria genera $[53,54]$. Moreover, members of Lachnospiraceae family - whose proportion increased at d 35 in our experiment-was positively correlated with intestinal epithelial cell energy metabolism and butyrate production [55, 56]. Ruminococcacecae spp. also was related to butyrate production [55]. Finally, a higher abundance of Bacteroides spp., Lachnospiraceae spp., and Ruminococcacecae spp. was linked to obese animals [57-59]. All these arguments are in line with the better performances observed at the end of the experimental period in our experiment. Also, piglets fed RDP diet had a higher acetic acid concentration in colon [13], and butyrate-producing bacteria are able to use acetate [60]. For example, a positive correlation between concentration of acetic acid and butyric acid in colon of pigs fed diets with increasing inclusion of chicory forage was reported by a previous finding [60], and [61] reported that OA induced adipose phenotypes. Thus, RDP diets alter not only composition of colonic microbiota but also microbiota metabolism. In addition, [51] found that microbiota can improve host fat storage. The OA controlled metabolic regulation by signal via G-protein-coupled receptors (GPCRs), such as GPR41relative to the adipose tissues, and effects of the microbiota on fat deposition depends on this OA receptor [62]. However, further studies are needed to clarify the effects of microbiota composition on colonic gene expression profiling.

\section{CONCLUSION}

This study indicated that weaned pigs fed RDP modulated the gastrointestinal microbiota composition over the period, especially at the highest inclusion levels, with higher abundance of population bacteria susceptible to improve fat deposition and animal performance. Negative effects of $\mathrm{RDP}$ on digestibility of several nutrients should be confirmed but, in the case of nitrogen, could be reflect shift in nitrogen flux. The effects of RDP on some plasma parameters have to be taken with caution due to their normal value ranges. Further studies are needed to highlight possible relationships between RDP-associated gut microbiota metabolism and pig growth physiology.

\section{CONFLICT OF INTEREST}

We certify that there is no conflict of interest with any financial organization regarding the material discussed in the manuscript. Fall PA is an employee of Genalyse Partner SA.

\section{ACKNOWLEDGMENTS}

This study was funded partly from ARES (Académie de Recherche et d'Enseignement Supérieur, fédération des établissements d’enseignement supérieur de la Fédération Wallonie-Bruxelles) thanks to a fund from the Belgian Development Cooperation, and partly by a postgraduate scholarship supported from the Vietnamese Ministry of Agriculture and Rural Development under Agriculture and Fisheries Biotechnology Program. The authors thank Dr. Moula Nassim (Faculty of Veterinary Medicine, University of Liège, Belgium) for his advice in use of experimental animals.

\section{REFERENCES}

1. Manh LH, Dung NNX, Kinh LV, Binh TC, Hang BPT, Phuoc TV. Composition and nutritive value of rice distillers' byproduct (hem) for small-holder pig production. Livest Res Rural Dev 2009;21:224.

2. Hong TTT, An LV, Phuong DT, Huy HA. Effect of rice distille's residue originating from alcohol production on growth performance, microflora, morphology of small intestine of weaning pigs. Sci Technol J Agric Rural Dev. 2013;3:147-56.

3. Chatterjee A, Bhakat C, Dey D, Yadava AS, Ghosh MK, Dutta TK. Nutritional potential of rice based distillery by-products for feeding of dairy cattle. Life Sci Int Res J 2017;4:19-21. https:// www.imrfournals.com/lsirj41

4. Huang HJ, Chiou PW-SC, Chen CR, Chiang JK, Yu B. Effects of dried rice distillers' and grain supplementation on the performance of lactating cows. Anim Feed Sci Technol 1999; 77:303-15. https://doi.org/10.1016/S0377-8401(98)00249-1

5. Pakhira MC, Biswas P. Effect of wet rice distillers grain and solubles on milk production and composition in lactating cows. Int J Curr Microbiol Appl Sci. 2018;7:1845-50. https:// doi.org/10.20546/ijcmas.2018.709.224

6. Manh LH, Dung NNX, Lindberg JE. Effects of replacement of fish meal with rice distiller's waste (hem) on performance and carcass quality of growing pigs. In: Proceeding Final Natl Semin Sustain Livest Prod local Feed Resour; 2003 Mar 25-28: HUAF-SAREC, Hue City, Vietnam.

7. Pluske JR, Pethick DW, Hopwood DE, Hampson DJ. Nutritional influences on some major enteric bacterial diseases of pig. Nutr Res Rev 2002;15:333-71. https://doi.org/10.1079/ NRR200242 
8. Pluske JR, Turpin DL, Kim JC. Gastrointestinal tract (gut) health in the young pig. Anim Nutr 2018;4:187-96. https:// doi.org/10.1016/j.aninu.2017.12.004

9. Boas ADCV, Budiño FEL, Neto MAT, et al. Organic acids in diets of weaned piglets: performance, digestibility and economical viability. Arq Bras Med Vet Zootec 2016;68:1015-22. http://dx.doi.org/10.1590/1678-4162-8501

10. Patil AK, Kumar S, Verma AK, Baghel RPS. Probiotics as feed additives in weaned pigs: a review. Livest Res Int 2015;3:31-9.

11. de Lange CFM, Pluske J, Gong J, Nyachoti CM. Strategic use of feed ingredients and feed additives to stimulate gut health and development in young pigs. Livest Sci 2010;134:124-34. https://doi.org/10.1016/j.livsci.2010.06.117

12. Pedersen C, Roos S, Jonsson H, Lindberg JE. Performance, feeding behaviour and microbial diversity in weaned piglets fed liquid diets based on water or wet wheat-distillers grain. Arch Anim Nutr 2005;59:165-79. https://doi.org/10.1080/17450 390500147875

13. Hong TTT, Thuy TT, Passoth V, Lindberg JE. Gut ecology, feed digestion and performance in weaned piglets fed liquid diets. Livest Sci 2009;125:232-7. https://doi.org/10.1016/j. livsci.2009.04.013

14. Hong TTT, Passoth V, Lindberg JE. Bacterial diversity at different sites of the digestive tract of weaned piglets fed liquid diets. Asian-Australas J Anim Sci 2011;24:834-43. https://doi.org/ 10.5713/ajas.2011.10291

15. Sivilai B, Preston TR, Hang DT, Linh NQ. Effect of a $4 \%$ dietary concentration of rice distillers' byproduct, or of brewers' grains, on growth rate and feed conversion during pregnancy and lactation of native Moo Lath gilts and their progeny. Livest Res Rural Dev 2018;30:20.

16. Sivilai B, Preston TR. A low concentration of rice distillers' byproduct, or of brewers' grains, increased diet digestibility and nitrogen retention in native Moo Lath pigs fed ensiled banana pseudo-stem (Musa spp) and ensiled taro foliage (Colocasia esculenta). Livest Res Rural Dev 2017;29:123.

17. Serena A, Jørgensen H, Bach Knudsen KE. Digestion of carbohydrates and utilization of energy in sows fed diets with contrasting levels and physicochemical properties of dietary fiber. J Anim Sci 2008;86:2208-16. https://doi.org/10.2527/ jas.2006-060

18. Rodriguez C, Taminiau B, Korsak N, et al. Longitudinal survey of Clostridium difficile presence and gut microbiota composition in a Belgian nursing home. BMC Microbiol 2016;16:229. https://doi.org/10.1186/s12866-016-0848-7

19. Schloss PD, Westcott SL, Ryabin T, et al. Introducing mothur: Open-source, platform-independent, community-supported software for describing and comparing microbial communities. Appl Environ Microbiol 2009;75:7537-41. https://doi. org/10.1128/AEM.01541-09

20. Rognes T, Flouri T, Nichols B, Quince C, Mahé F. VSEARCH: a versatile open source tool for metagenomics. Peer J 2016;4: e2584. https://doi.org/10.7717/peerj.2584

21. Quast C, Pruesse E, Yilmaz P, et al. The SILVA ribosomal RNA gene database project: Improved data processing and webbased tools. Nucleic Acids Res 2013;41:D590-6. https://doi. org/10.1093/nar/gks1219

22. Martin AP. Phylogenetic approaches for describing and comparing the diversity of microbial communities. Appl Environ Microbiol 2002;68:3673-82. https://doi.org/10.1128/AEM.68. 8.3673-3682.2002

23. Vegan: community ecology package [Internet]. R package version 2.4-5 [cited 2017 Jan 17]. Available from: https://CRAN. R-project.org/package=vegan

24. Vegan3d: static and dynamic 3D plots for the "vegan" package [Internet]. R package version 1.1-1 [cited 2017 Dec 1]. Available from: https://CRAN.R-project.org/package=vegan3d

25. Package "rgl": 3D visualization using openGL [Internet]. $\mathrm{R}$ package version 0.98 .1 [cited 2018 Jan 13]. Available from: https://CRAN.R-project.org/package $=$ rgl

26. R: A language and environment for statistical computing [Internet]. Foundation for statistical computing, Vienna, Austria [cited 2017 Dec 1]. Available from: https://www. r-project.org/

27. AOAC. Official Methods of Analysis. 15th ed. Arlington, VA, USA: Association of Official Analytical Chemists; 1990.

28. Hunt JR. Feedstuffs analysis, rapid determination of calcium in feedstuffs. J Agric Food Chem 1963;11:346-7. https://doi. org/10.1021/jf60128a024

29. Miller GL. Use of dinitrosalicylic acid reagent for determination of reducing sugar. Anal Chem 1959;31:426-8. https:// doi.org/10.1021/ac60147a030

30. Williams CH, David DJ, lismaa O. The determination of chromic oxide in faeces samples by atomic absorption spectrophotometry. J Agric Sci 1962;59:381-5. https://doi.org/10.1017/ S002185960001546X

31. Widmer MR, McGinnis LM, Wulf DM, Stein HH. Effects of feeding distillers dried grains with solubles, high-protein distillers dried grains, and corn germ to growing-finishing pigs on pig performance, carcass quality, and the palatability of pork. J Anim Sci 2008;86:1819-31. https://doi.org/10.2527/ jas.2007-0594

32. Parks DH, Tyson GW, Hugenholtz P, Beiko RG. STAMP: statistical analysis of taxonomic and functional profiles. Bioinformatics 2014;30:3123-4. https://doi.org/10.1093/ bioinformatics/btu494

33. Van Winsen RL, Urlings BAP, Lipman LJA, et al. Effect of fermented feed on the microbial population of the gastrointestinal tracts of pigs. Appl Environ Microbiol 2001;67:3071-6. https://doi.org/10.1128/AEM.67.7.3071-3076.2001

34. Fan P, Liu P, Song P, Chen X, Ma X. Moderate dietary protein restriction alters the composition of gut microbiota and improves ileal barrier function in adult pig model. Sci Rep 2017; 7:43412. https://doi.org/10.1038/srep43412 
35. Choct M, Kocher A. Non-starch carbohydrates-digestion and its secondary effects in monogastrics. Proceeding Nutr Soc Aust 2000;24:31-8.

36. Williams BA, Grant LJ, Gidley MJ, Mikkelsen D. Gut fermentation of dietary fibres: Physico-chemistry of plant cell walls and implications for health. Int J Mol Sci 2017;18:2203. https:// doi.org/10.3390/ijms18102203

37. Montagne L, Pluske JR, Hampson DJ. A review of interactions between dietary fibre and the intestinal mucosa, and their consequences on digestive health in young non-ruminant animals. Anim Feed Sci Technol 2003;108:95-117. https:// doi.org/10.1016/S0377-8401(03)00163-9

38. Li J, Kim IH. Effects of levan-type fructan supplementation on growth performance, digestibility, blood profile, fecal microbiota, and immune responses after lipopolysaccharide challenge in growing pigs. J Anim Sci 2013;91:5336-43. https://doi.org/ 10.2527/jas.2013-6665

39. Chung HJ, Liu Q, Lee L, Wei D. Relationship between the structure, physicochemical properties and in vitro digestibility of rice starches with different amylose contents. Food Hydrocoll 2011;25:968-75. https://doi.org/10.1016/j.foodhyd. 2010.09.011

40. Pascoal LAF, Thomaz MC, Watanabe PH, et al. Fiber sources in diets for newly weaned piglets. Rev Bras Zootec 2012;41: 636-42. http://dx.doi.org/10.1590/S1516-35982012000300024

41. Agyekum AK, Slominski BA, Nyachoti CM. Organ weight, intestinal morphology, and fasting whole-body oxygen consumption in growing pigs fed diets containing distillers dried grains with solubles alone or in combination with a multienzyme supplement. J Anim Sci 2012;90:3032-40. https://doi. org/10.2527/jas.2011-4380

42. Święch E, Tuśnio A, Taciak M, Boryczka M, Buraczewska L. The effects of pectin and rye on amino acid ileal digestibility, threonine metabolism, nitrogen retention, and morphology of the small intestine in young pigs. J Anim Feed Sci 2012;21: 89-106. https://doi.org/10.22358/jafs/66055/2012

43. Drochner W, Kerler A, Zacharias B. Pectin in pig nutrition, a comparative review. J Anim Physiol Anim Nutr 2004;88:36780. https://doi.org/10.1111/j.1439-0396.2004.00490.x

44. Xu YT, Liu L, Long SF, Pan L, Piao XS. Effect of organic acids and essential oils on performance, intestinal health and digestive enzyme activities of weaned pigs. Anim Feed Sci Technol 2018;235:110-9. https://doi.org/10.1016/j.anifeedsci.2017. 10.012

45. Saleh MAD, Amorim AB, Grecco HAT, et al. Effects of $\beta-(1 \rightarrow 3$, $1 \rightarrow 6)$-d-glucan and density of diets on the blood profiles of immunologically challenged weaned piglets. Int J Biol Macromol 2015;80:659-67. https://doi.org/10.1016/j.ijbiomac. 2015.07.024

46. Trckova M, Prikrylova VH, Zraly Z, Sramkova ZZ, Kummer $\mathrm{V}$, Alexa P. The effect of dietary bentonite on post-weaning diarrhoea, growth performance and blood parameters of weaned piglets. Appl Clay Sci 2014;90:35-42. https:/doi.org/ 10.1016/j.clay.2013.11.009

47. Huang Y, Yoo JS, Kim HJ, et al. Effects of dietary supplementation with blended essential oils on growth performance, nutrient digestibility, blood profiles and fecal characteristics in weanling pigs. Asian-Australas J Anim Sci. 2010;23:60713. https://doi.org/10.5713/ajas.2010.80120

48. Clark SG, Coffer N. Normal hematology and hematologic disorders in potbellied pigs. Vet Clin North Am Exot Anim Pract 2008;11:569-82. https://doi.org/10.1016/j.cvex.2008.03. 003

49. Vrese M, Marteau PR. Probiotics and prebiotics: effects on diarrhea. J Nutr 2007;137:803S-11S. https://doi.org/10.1093/ jn/137.3.803S

50. Wang J, Han Y, Meng F, Zhao J, Zhou Z, Fan H. Fecal microbiota succession of piglets from birth to post-weaning by 454 pyrosequencing analysis. Trans Tianjin Univ 2017;23:211-20. https://doi.org/10.1007/s12209-017-0045-2

51. Rajoka MSR, Shi J, Mehwish HM, et al. Interaction between diet composition and gut microbiota and its impact on gastrointestinal tract health. Food Sci Hum Wellness 2017;6:12130. https://doi.org/10.1016/j.fshw.2017.07.003

52. Liu P, Zhao J, Wang W, Guo P, Lu W, Wang C. Dietary corn bran altered the diversity of microbial communities and cytokine production in weaned pigs. Front Microbiol 2018;9: 2090. https://doi.org/10.3389/fmicb.2018.02090

53. Bajpai P. Xylan: Occurrence and structure. Xylanolytic enzym. Oxford, UK: Academic Press; 2014. p. 9-18. https://doi.org/ 10.1016/B978-0-12-801020-4.00002-0

54. Stein HH, Casas GA, Abelilla JJ, Liu Y, Sulabo RC. Nutritional value of high fiber co-products from the copra, palm kernel, and rice industries in diets fed to pigs. J Anim Sci Biotechnol 2015;6:56. https://doi.org/10.1186/s40104-015-0056-6

55. Wang J, Qin C, He T, et al. Alfalfa-containing diets alter luminal microbiota structure and short chain fatty acid sensing in the caecal mucosa of pigs. J Anim Sci Biotechnol 2018;9:11. https://doi.org/10.1186/s40104-017-0216-y

56. Louis P, Scott KP, Duncan SH, Flint HJ. Understanding the effects of diet on bacterial metabolism in the large intestine. J Appl Microbiol 2007;102:1197-208. https://doi.org/10.1111/ j.1365-2672.2007.03322.x

57. He M, Fang S, Huang X, et al. Evaluating the contribution of gut microbiota to the variation of porcine fatness with the cecum and fecal samples. Front Microbiol 2016;7:2108. https:// doi.org/10.3389/fmicb.2016.02108

58. Schwiertz A, Taras D, Schäfer K, et al. Microbiota and SCFA in lean and overweight healthy subjects. Obesity 2010;18:1905. https://doi.org/10.1038/oby.2009.167

59. Zhao L, Zhang Q, Ma W, Tian F, Shen H, Zhou M. A combination of quercetin and resveratrol reduces obesity in high-fat diet-fed rats by modulation of gut microbiota. Food Funct 2017;8:4644-56. https://doi.org/10.1039/C7FO01383C 
60. Liu H, Ivarsson E, Dicksved J, Lundh T, Lindberg JE. Inclusion of chicory (Cichorium intybus L.) in pigs' diets affects the intestinal microenvironment and the gut microbiota. Appl Environ Microbiol 2012;78:4102-9. https://doi.org/10.1128/ AEM.07702-11

61. Cho I, Yamanishi S, Cox L, et al. Antibiotics in early life alter the murine colonic microbiome and adiposity. Nature 2012;
488:621-6. https://doi.org/10.1038/nature11400

62. Tremaroli V, Bäckhed F. Functional interactions between the gut microbiota and host metabolism. Nature 2012;489:242-9. https://doi.org/10.1038/nature11552

63. Noblet J, Perez JM. Prediction of digestibility of nutrients and energy values of pig diets from chemical analysis. J Anim Sci 1993;71:3389-98. https://doi.org/10.2527/1993.71123389x 